\title{
Hedyselmis opis: Description of the larva and its phylogenetic relation to Graphelmis (Coleoptera: EImidae: Elminae)
}

\author{
FEDOR ČIAMPOR ${ }^{1} J_{R}$. and IGNACIO RIBERA ${ }^{2}$ \\ ${ }^{1}$ Institute of Zoology, Slovak Academy of Sciences, Dúbravská cesta 9, SK-84506 Bratislava, Slovakia; e-mail: f.ciampor@savba.sk \\ ${ }^{2}$ Departamento de Biodiversitad y Biología Evolutiva, Museo Nacional de Ciencias Naturales, José Gutiérrez Abascal 2, E-28006 \\ Madrid, Spain; e-mail: i.ribera@mncn.csic.es
}

Key words. Hedyselmis, Graphelmis, Coleoptera, Elmidae, larva, description, phylogeny

\begin{abstract}
The riffle beetle genus Hedyselmis Hinton, 1976 includes two species from the Malay Peninsula, with adults with a highly deviating morphology. Its phylogenetic relationships are unclear, although it has been hypothesized to be related to Graphelmis Delève, 1968, a large genus widely distributed in the Oriental and East Palaearctic regions. In this paper the larva of H. opis Hinton, 1976 is described based on material collected in the Cameron Highlands (Malaysia) and the conspecificity with co-existing adults tested using sequences of one nuclear (5' end of $18 \mathrm{~S}$ rRNA) and three mitochondrial gene fragments (5' end of the large ribosomal unit + tRNAleu + 5' end of the NADH dehydrogenase subunit 1; 5' end of cytochrome c oxidase subunit I; and a fragment of cytochrome b) with a total of ca. 2,600 bp. This is the first example of the use of molecular data to match different life stages within the family Elmidae. The larva of $H$. opis has a subcylindrical body typical of many other elmid genera; abdominal segments $1-7$ with preserved pleura; and ninth segment with oval operculum. The last instar larvae have clearly visible prominent spiracles on mesothorax and abdominal segments 1-8. The phylogenetic position of Hedyselmis in relation to Graphelmis was investigated using molecular data for three species of Graphelmis plus a selection of other Elmidae genera. Hedyselmis opis is nested within Graphelmis, confirming their close relationship and suggesting that their status requires taxonomic revision.
\end{abstract}

\section{INTRODUCTION}

Other than for several well known genera, descriptions of elmid larvae, especially from tropical regions, are rarely found in the literature. The major problem lies in the high diversity of the material collected and the difficulty of assigning larvae to conspecific adults. The most reliable method of determining elmid larvae to species is to rear them under laboratory conditions, which is usually very difficult due to the habitat requirements and the length of larval development (Brown, 1987). Thus, the description of larvae is normally confined to species collected with only one representative of the family or with clearly unrelated species. An alternative way of matching adults with larvae is by using DNA sequences with the appropriate level of variation (i.e., with enough variability for there to be differences among closely related species but not enough to impede recognition). There are surprisingly few examples of this use of DNA sequences (e.g., Balke et al., 2005; Jeon \& Ahn, 2005; Miller et al., 2005), despite the increasing availability of molecular facilities and their wide use in forensic science (e.g., Wells \& Sperling, 2001). Previous descriptions of Elmidae larvae are based exclusively on morphological characters (e.g., Manzo \& Archangelsky, 2001; Springer \& Acosta, 2003) and this is the first study to use molecular data to assign larvae to specific adults within the Elmidae.

Hinton (1976) described the genus Hedyselmis based on six females of one species, H. opis, from the Malay Peninsula. Only recently the males of $H$. opis and one additional congeneric species were described, also from the Malay Peninsula (Jäch \& Boukal, 1997). Adults of both species of Hedyselmis have unusual morphology and seem to be most closely related to the genus Graphelmis (Jäch \& Boukal, 1997; Čiampor Jr., unpubl.). In 2001 some additional material of $H$. opis, together with unknown elmid larvae, was collected by the junior author in the Malay Peninsula. The lack of any other species of Elmidae at that locality made it likely that the larvae belonged to the same species.

The aim of the current study was to describe the unknown Elmidae larva and using four molecular markers to test the hypothesis that it belongs to the species Hedyselmis opis. The molecular data was also used to outline possible relationship between Hedyselmis and Graphelmis, as suggested most closely related genus.

\section{MATERIAL AND METHODS}

\section{Taxon sampling}

Eight specimens of putative Hedyselmis opis larvae were examined from the following locality data as follows: "Malaysia, Pahang, Cameron Highlands, Tanah Rata env.; small, shaded stream crossing path Nr. 9 surrounded by primary forest; 9. VI. 2001. Shaded, very shallow stream, 0.5-1.0 m wide, flowing in dense primary forest on steep slope, with small waterfalls; bottom littered with submerged wood". At this locality, the larvae were collected in association with adults of $H$. opis and some species of Dryopidae.

For the phylogenetic analysis of Hedyselmis opis three species of the genus Graphelmis were used as the likely sister group (Jäch \& Boukal, 1997), plus some other genera of Elmidae (Table 1). The tree was rooted in a genus of a related family (Dryopidae), Pomatinus Sturm, 1806. 
TABLE 1. Geographical origin, collectors and Genbank accession numbers of the taxa studied.

\begin{tabular}{|c|c|c|c|c|c|c|}
\hline Species & Locality & Collector & $18 \mathrm{~S}$ & Coxl & $c o b$ & $16 \mathrm{~S}$ \\
\hline Hedyselmis opis Hinton, 1976 larva & Malaysia & Čiam & DQ005516 & DQ005514 & DQ005512 & DQ005518 \\
\hline Hedyselmis opis Hinton, 1976 adult & Malaysia & Čiampor Jr. & DQ005517 & DQ005515 & DQ005513 & DQ005519 \\
\hline Graphelmis obesa Čiampor Jr., 2005 & Malaysia & Čiampor Jr. & DQ266481 & DQ266492 & DQ266503 & DQ266471 \\
\hline $\begin{array}{l}\text { Graphelmis picea Čiampor Jr. \& Kodada, } \\
2005\end{array}$ & $\begin{array}{l}\text { Papua New } \\
\text { Guinea }\end{array}$ & Balke & DQ266482 & DQ266493 & DQ266504 & DQ266472 \\
\hline Graphelmis clermonti (Pic, 1923) & Laos & Jendek \& Šauša & DQ266483 & DQ266494 & DQ266505 & DQ266473 \\
\hline Stenelmis sp. & Malaysia & Čiampor Jr. & DQ266484 & DQ266495 & DQ266506 & DQ266474 \\
\hline Limnius intermedius Fairmaire, 1881 & Spain & Ribera & DQ266485 & DQ266496 & DQ266507 & DQ266475 \\
\hline Oulimnius tuberculatus (Müller, 1806) & Spain & Ribera & DQ266486 & DQ266497 & DQ266508 & DQ266476 \\
\hline Dubiraphia sp. & USA & Ribera \& Cieslak & DQ266487 & DQ266498 & DQ266509 & DQ267445 \\
\hline $\begin{array}{l}\text { Rhopalonychus levatorponderis Jäch \& } \\
\text { Kodada, } 1996\end{array}$ & Malaysia & Čiampor Jr. & DQ266488 & DQ266499 & DQ266510 & DQ266477 \\
\hline Ancyronyx procerus Jäch, 1994 & Malaysia & Čiampor Jr. & DQ266489 & DQ266500 & DQ266511 & DQ266478 \\
\hline Potamophilinus sp. & Malaysia & Čiampor Jr. & DQ266490 & DQ266501 & DQ266512 & DQ266479 \\
\hline Pomatinus substriatus (Müller, 1806) & Spain & Ribera & DQ266491 & DQ266502 & DQ266513 & DQ266480 \\
\hline
\end{tabular}

\section{Morphological analyses}

Specimens prepared for morphological study were cleaned and examined under a Nikon SMZ-1B stereo-microscope under diffuse lighting at magnifications up to $140 \times$. Mouth parts were dissected and placed in lactic acid for a few days before examination using a Carl Zeiss transmitted light microscope at magnifications up to $600 \times$. Drawings were made using a drawing tube.

For scanning electron microscopy, specimens were dehydrated in a graded ethanol series, air-dried from absolute ethanol, mounted on stubs using double-sided tape, sputter coated with gold and then viewed in a Hitachi S800 at $10 \mathrm{kV}$.

Metric characters were measured to the nearest $0.05 \mathrm{~mm}$ using a Nikon SMZ-1B with an ocular grid. Morphological terms follow Lawrence (1991).

\section{Molecular methods}

One adult of each species and one unknown larva were used for non-destructive DNA extraction. These individuals are kept as voucher specimens in the collection of the junior author and DNA aliquotes are kept in the MNCN Madrid, ref. No. FC-C17 (larva), and adults FC-A11 (H. opis), FC-D16 (G. obesa), FC-D14 (G. clermonti), FC-D02 (Stenelmis sp.), FC-B10 (Limnius intermedius), FC-D05 (Oulimnius tuberculatus), FC-E10 (Dubiraphia sp.), FC-B01 (Rhopalonychus levatorponderis), FC-B05 (Ancyronyx procerus), FC-A16 (Potamophilinus sp.), FC-B11 (Pomatinus substriatus).

DNA was extracted from whole specimens using the Qiagen DNeasy tissue kit. Four fragments were amplified using PCR; three mitochondrial [ $826 \mathrm{bp}$ from the 3' end of the cytochrome oxidase subunit I (coxl), 358 bp of the cytochrome b apoenzyme (cob), and 835 bp comprising the 3 ' end of the $\operatorname{rrnL}(16 \mathrm{~S}$ rRNA), the adjacent transfer RNA leucine 2 (tRNAleu), and part of NADH dehydrogenase subunit 1 (nadl)] and one nuclear (602 bp of the 5' end of the ribosomal 18S rRNA gene) (see Table 2 for the primers used). Amplification products were purified using Qiagen Qiaquick PCR purification columns and sequenced in both directions. Sequences were sent to GenBank and have accession numbers DQ005512-DQ005519, DQ266471-DQ266513 and DQ267445 (Table 1).

\section{Phylogenetic analyses}

Protein-coding genes were not length variable and there was little variation in the ribosomal genes within Elmidae (length of the 18S rRNA fragment was between 626 and $628 \mathrm{bp}$; of the 16S rRNA fragment between 817 and $827 \mathrm{bp}$ ). The sequences were aligned manually. The combined data matrix (all four genes) was analysed using parsimony in PAUP* software version 4.0b10 (Swofford, 2002), with a TBR heuristic search of 10,000 replicates and the option 'save multiple trees' activated. For comparison with the Bayesian probability results (see below), gaps in all searches were coded as missing characters, although treating them as a $5^{\text {th }}$ character state did not change the topology of the trees (not shown). Node support was measured using Bremer Support (PBS) values (Bremer, 1994) on constraint trees generated by means of TreeRot.v2 (Sorenson, 1996) and non-parametric bootstrapping (Felsenstein, 1985) using 1,000 pseudoreplicates of 50 random additions each.

TABLE 2. Primers used in this study.

\begin{tabular}{lcclc}
\hline Gene & Name & Sense & \multicolumn{1}{c}{ Sequence } & Reference \\
\hline coxl & Jerry & F & CAACATTTATTTTGATTTTTTGG & Simon et al., 1994 \\
& Pat & R & TCCAATGCACTAATCTGCCATATTA & Simon et al., 1994 \\
Cob & CB3 & F & GAGGAGCAACTGTAATTACTAA & Barraclough et al., 1999 \\
& CB4 & R & AAAAGAAA(AG)TATCATTCAGGTTGAAT & Barraclough et al., 1999 \\
$16 \mathrm{~S}+$ nad1 & $16 \mathrm{~s} \mathrm{aR}$ & $\mathrm{F}$ & CGCCTGTTTAACAAAAACAT & Simon et al., 1994 \\
& ND1A & R & GGTCCCTTACGAATTTGAATATATCCT & Simon et al., 1994 \\
$18 \mathrm{~S}$ & $18 \mathrm{~S} 5{ }^{\prime}$ & $\mathrm{F}$ & GACAACCTGGTTGATCCTGCCAGT(1) & Shull et al., 2001 \\
& $18 \mathrm{~S}$ b5.0 & $\mathrm{R}$ & TAACCGCAACAACTTTAAT(1) & Shull et al., 2001 \\
\hline
\end{tabular}

$\mathrm{F}$ - forward; $\mathrm{R}$ - reverse. 

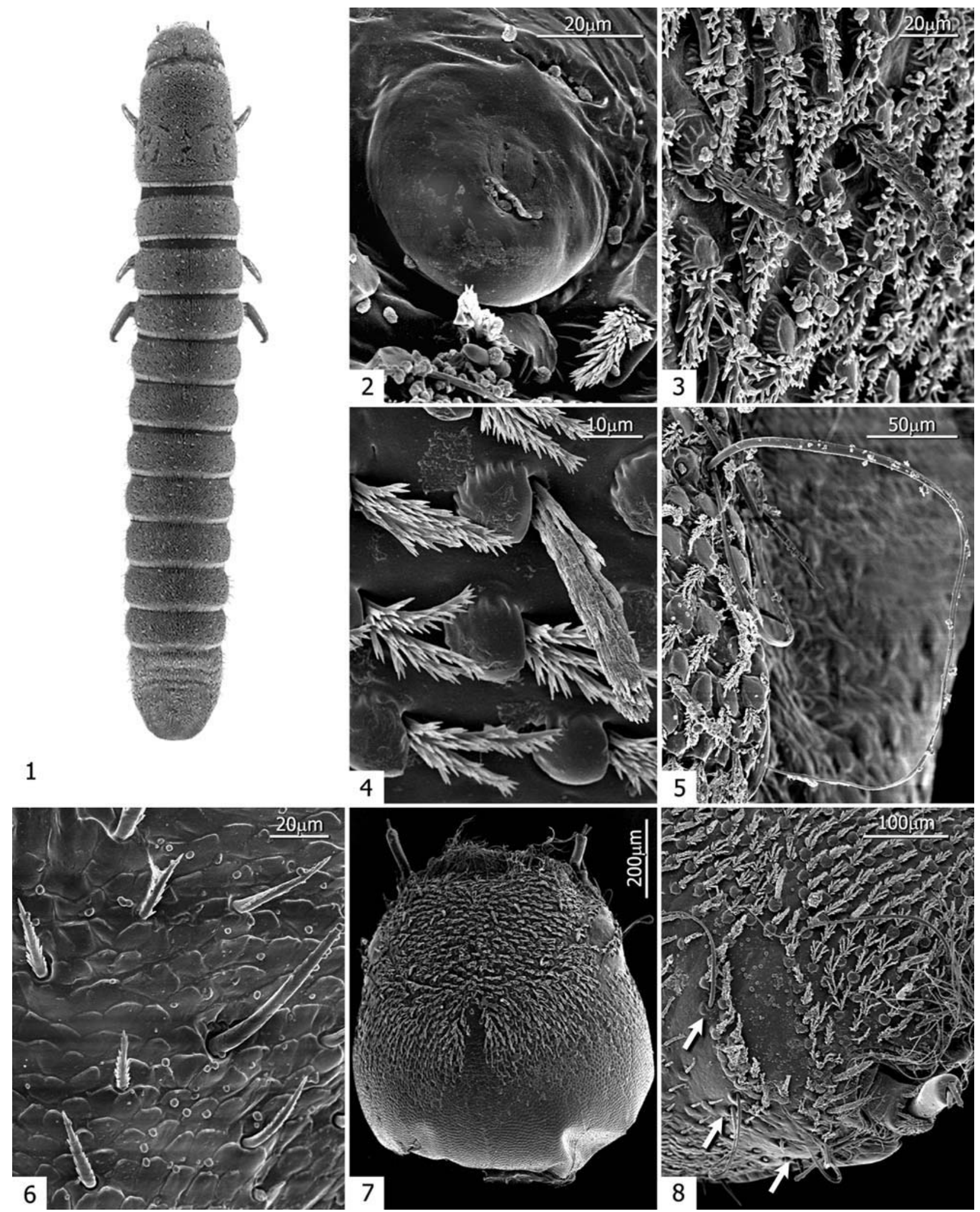

Figs 1-8. Hedyselmis opis larva: 1 - habitus; 2 - biforous spiracle; $3-6$ - surface setae (3-5 - dorsal side, 6 - ventral side); 7 head, dorsal view; 8 - stemmata, dorso-lateral view, arrows show elongate setae surrounding eyes.

Bayesian analyses were executed with MrBayes 3.04 (Huelsenbeck \& Ronquist, 2001), using a GTR + I + G model as selected by Modeltest 3.6 (Posada \& Crandall, 1998), with the parameters estimated for each partition (i.e., gene fragment). Searches were executed with default priors (uniform probabili- ties) starting with random trees with three heated and one cold Markov chains for 1,000,000 generations, sampled at intervals of 100 generations. To determine the point at which the Markov chains reached stationarity, the log-likelihood scores were plotted against generation time and the point when the likeli- 

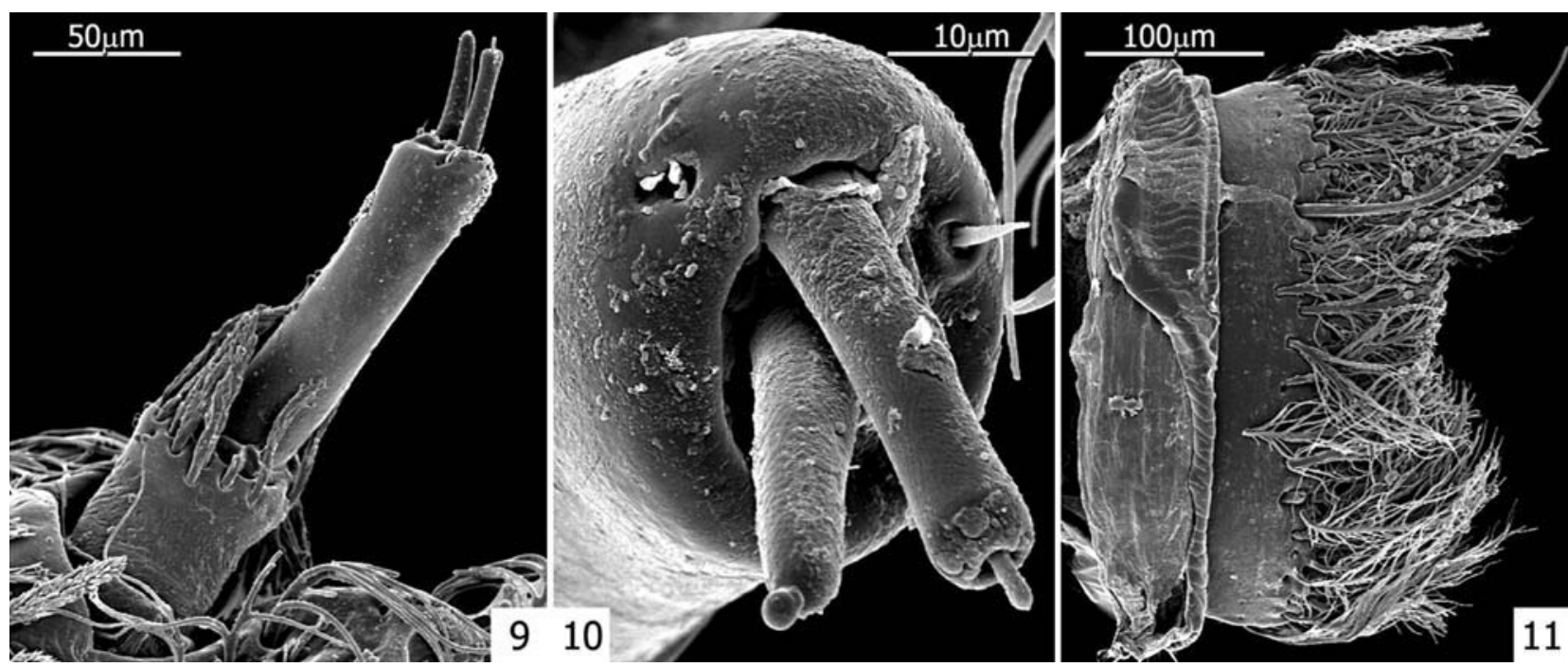

Figs 9-11. Hedyselmis opis larva: 9 - antenna, dorsal view; 10 - antennal flagellum and sensorium, apical view; 11 - labrum, dorsal view.

hood values reached a stable equilibrium visually determined. The parameter estimation (including tree topologies) obtained before reaching the stationary were discarded as a "burn-in" and only the trees sampled after that point were considered (Huelsenbeck \& Ronquist, 2001).

\section{RESULTS}

\section{Matching of adults and larvae}

The sequences of the nuclear gene (fragment of $18 \mathrm{~S}$ rRNA) of the elmid larva and adult Hedyselmis opis were identical. Among the mitochondrial genes, the only unambiguous difference was in the cob sequence, in which in position 352 the larva had a $\mathrm{T}$ and the adult a $\mathrm{C}$. This was a synonymous change in the third codon position. In both the sequences of the coxl and $16 \mathrm{~S}$ rRNA+nad1 of the adult there were some ambiguous positions (with double peaks in the chromatogram): in cox 1 , positions 157 and 166 had a $\mathrm{T}$ in the larva and $\mathrm{T}$ or $\mathrm{C}$ in the adult, positions 205 and 343 had $\mathrm{A}$ in the larva and $\mathrm{A}$ or $\mathrm{G}$ in the adult (all synonymous ambiguities in third codon positions); and in 16S rRNA, in positions 266 and 616, larva had G, adult A or G. All ambiguous positions were in sections of high quality sequence, without any ambiguous chromatogram in nearby positions. The total uncorrected genetic divergence between the two specimens was thus between $0.04 \%$ (if all ambiguities are resolved as matches) and $0.27 \%$ (when all ambiguities are resolved as mismatches). For the mitochondrial genes only, the divergence ranges from $0.05-0.35 \%$.

\section{Phylogenetic analysis}

The combined aligned matrix had 2,717 characters (cox1 826, cob 407, 16S 853, 18S 631). Within the whole dataset, there were 628 parsimony informative characters (658 when gaps were treated as a $5^{\text {th }}$ character state). Heuristic searches resulted in a single most parsimonious tree (consistency index $\mathrm{CI}=0.51$, retention index $\mathrm{RI}=0.37$ ). The sequences of the larva and adult of $H$. opis were grouped together with high support (100\% bootstrap) and included within Graphelmis in a well supported clade (100\% bootstrap, 17 Bremer support, Fig. 44).

In the Bayesian analyses the sampled ML values reached stationarity at ca. 20,000 generations, but the first 100,000 (i.e., 1,000 trees) were discarded as a burn-in. The topology of the $50 \%$ majority rule consensus tree was almost identical to that of the parsimony tree, with the same highly supported nodes relating the larvae and adults of $H$. opis and the grouping of Hedyselmis within Graphelmis.

\section{Description of the larva of Hedyselmis opis}

Diagnosis. The larva of $H$. opis differs from the larvae presumably assigned to Graphelmis by: (1) dark brown colour; (2) shorter legs; (3) more flattened tufted scales of integument and (4) absence of paired dorsal spines on abdominal segment 9. Within Elmidae both, larva of $H$. opis and that assumed to belong to Graphelmis, differ by combination of the following characters: (1) body subcy-
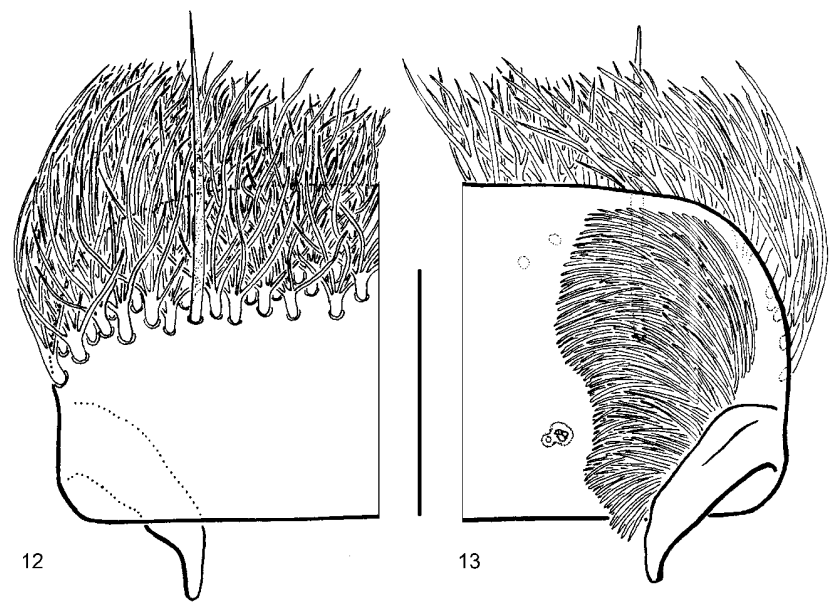

Figs 12-13. Hedyselmis opis larva: 12 - labrum, dorsal view; 13 - labrum, ventral view. Scale: $0.1 \mathrm{~mm}$. 

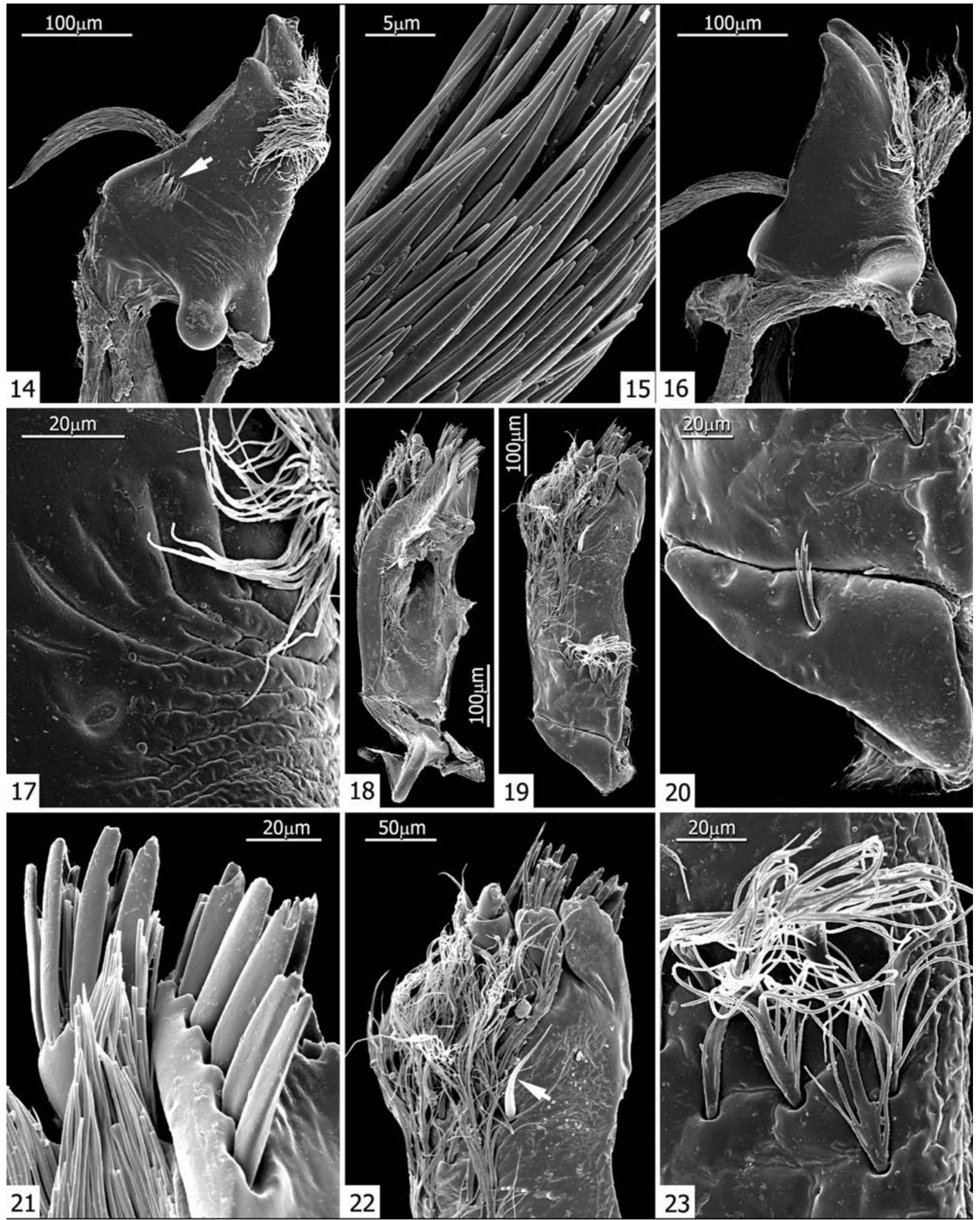

Figs 14-23. Hedyselmis opis larva: 14 - left mandible, ventral view; 15 - detail of articulated setose process of mandible, same view; 16 - right mandible, dorsal view; 17 - same, detail of oblique grooves; 18 - left maxilla, dorsal view; 19 - right maxilla, ventral view; 20 - right cardo, dorsal view; 21 - detail of maxillary apex, dorsal view; 22 - galea, lacinia and maxillary palpus, ventral view; 23 - detail of setal tuft on stipes, ventral view.

lindrical without flattened thoracic and abdominal segments; (2) dorsal side of segments without sagital carina; (3) abdominal pleura present on segments $1-7$; (4) abdominal segment 9 rounded apically in dorsal view, flattened and strongly slanting posteriad. 

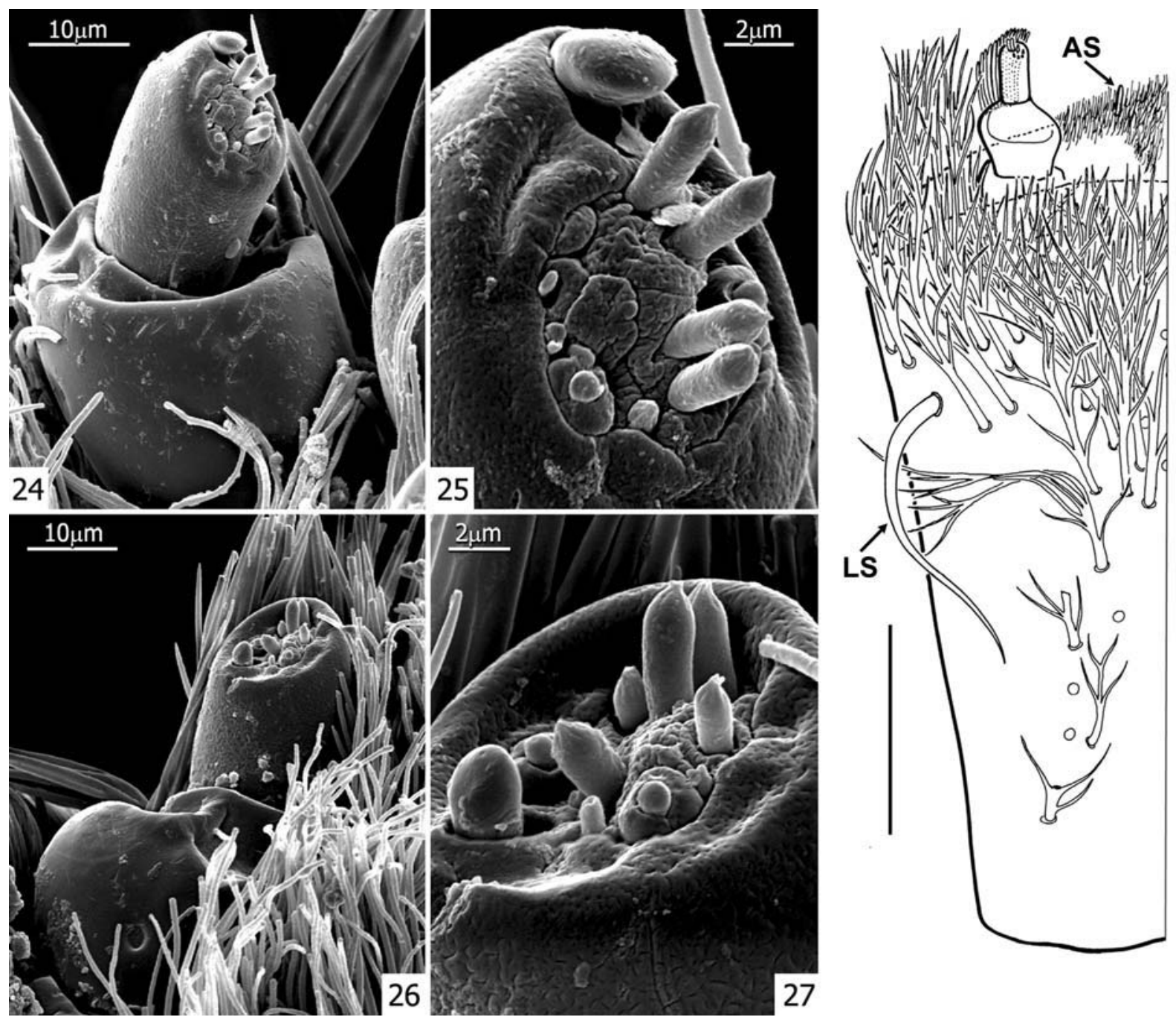

Figs 24-28. Hedyselmis opis larva: 24 - maxillary palpus, ventral view; 25 - apical sensory field of maxillary palpus, apical view; 26 - labial palpus, ventral view; 27 - same, detail of apical sensory field; 28 - labium, ventral side. AS - admedian sensillum, LS lateral seta. Scale: $0.1 \mathrm{~mm}$.

Habitus (Fig. 1). Length $8.3-8.8 \mathrm{~mm}$, greatest width 1.2-1.3 mm. Colour dark brown, ventral side and legs slightly lighter. Body elongate, subcylindrical, parallelsided, convex dorsally, almost flat ventrally. Biforous spiracles present laterally on mesothorax and abdominal segments 1-8 (Fig. 2). Integument with dense, light, tufted scales (Figs 3,4) and two types of sparse yellow setae: (1) long acuminate setae (Fig. 5); (2) shorter spiky setae (Fig. 6). Dorsal side of cranium, dorsal and lateral sides of thorax and abdomen microgranulate; ventral side rugose; genae microreticulate.

Head (Fig. 7) rounded, prognathous, partially retracted into prothorax, about as long as wide, without tooth on anterior margin between base of antenna and clypeus; epicranial sutures hardly visible. Stemmata clustered, forming a single "eye", distally surrounded by several distinctly long thin setae (Fig. 8). Antenna threesegmented (Fig. 9); scape widest, with subapical row of scale-like setae; pedicel elongate, about twice as long as scape; flagellum setiform with apical sensillum with blunt tip; sensorium as long as flagellum (Fig. 10). Labrum short, about twice as wide as long, with pair of distinctly long admedian setae; anterior third covered by dense yellowish branched scales (Fig. 11); tormae curved (Figs 12, 13); epipharynx with dense, mesally directed short setae on both sides (Fig. 13). Clypeus wider than long, microgranulate; frontoclypeal suture well indicated. Mandible (Figs 14-17) well developed, palmate, with three oblique apical teeth; incisor area with long curved articulated setose process (Figs 14-16); prostheca and mola absent; outer margin subapically with distinct tuft of long branched setae; ventral condyle rounded; ventral side with small tuft of short setae near insertion of articulated setose process (Fig. 14 arrow); dorsal side with oblique grooves beneath subapical setal tuft (Fig. 17). Maxilla (Figs 18-25) slender; cardo small, transverse, triangular with one mesal spiky seta (Fig. 20); stipes elongate, ventrally with transverse prebasal tuft of branched setae (Fig. 23) and subapical long acuminate sensillum (Fig. 22 arrow); outer margin with adherent branched setae; galea and lacinia subequally long, with truncate apex and with brush of stout, peg-like setae (Fig. 21); maxillary palpus 

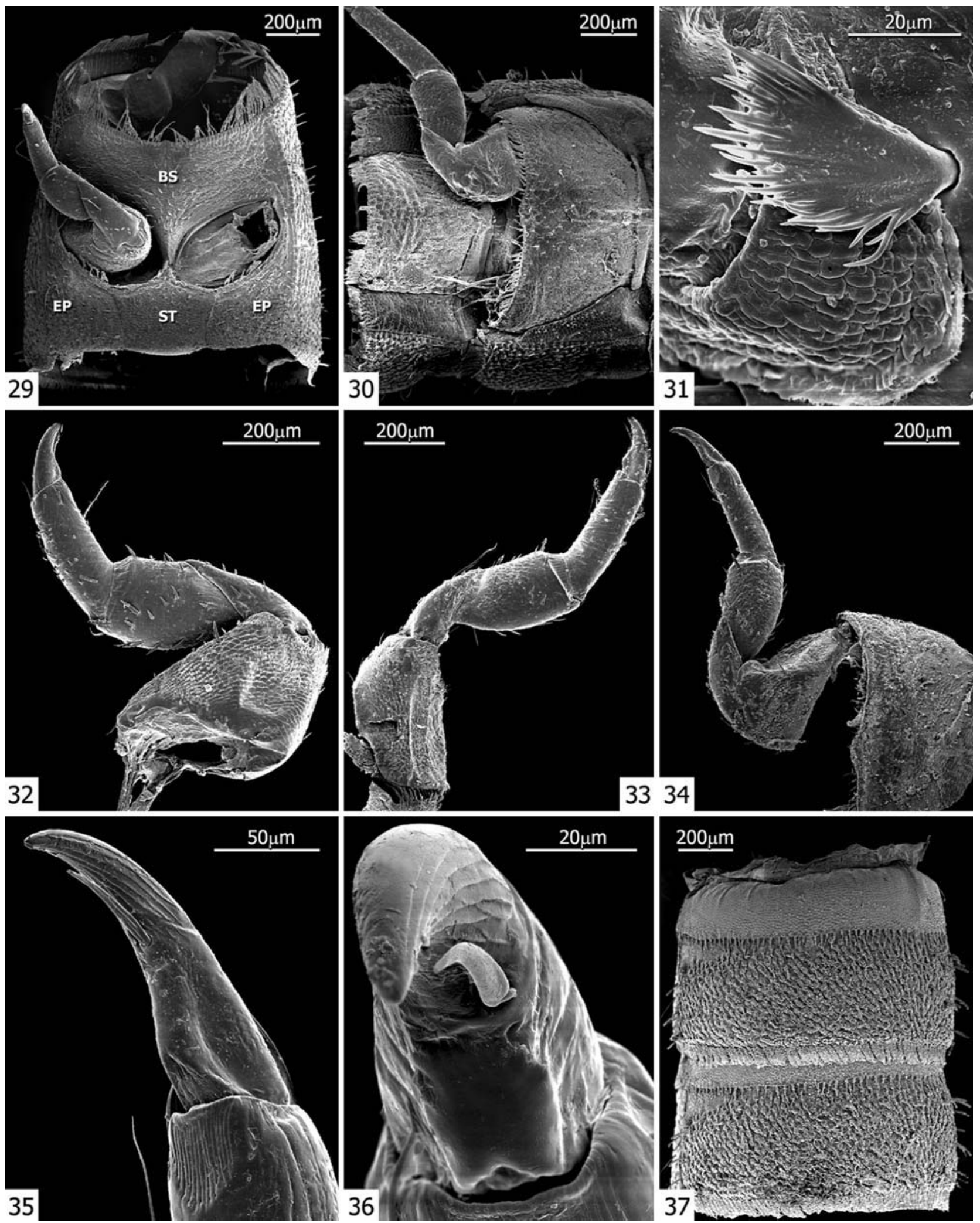

Figs 29-37. Hedyselmis opis larva: 29 - prosternum (BS - basisternum, EP - epimeron, ST - sternellum), ventral view; 30 metasternum, ventral view; 31 - spiky sensillum on trochanter, ventral view; 32 - left fore-leg, dorsal view; 33 - left mid-leg, ventral view; 34 - right hind-leg, ventral view; 35 - claw, ventral view; 36 - same, detail of ventral seta; 37 - abdominal tergites 1-2, dorsal view.

(Fig. 24) four-segmented, slightly longer than galea; apical sensory field of distal segment with some four types of sensilla (Fig. 25). Labium (Figs 26-28). Pre- mentum short, transverse, membranous; ligula setose with two admedian sensilla; labial palpi two-segmented; segment 1 subglobular with dense row of long setae; segment 

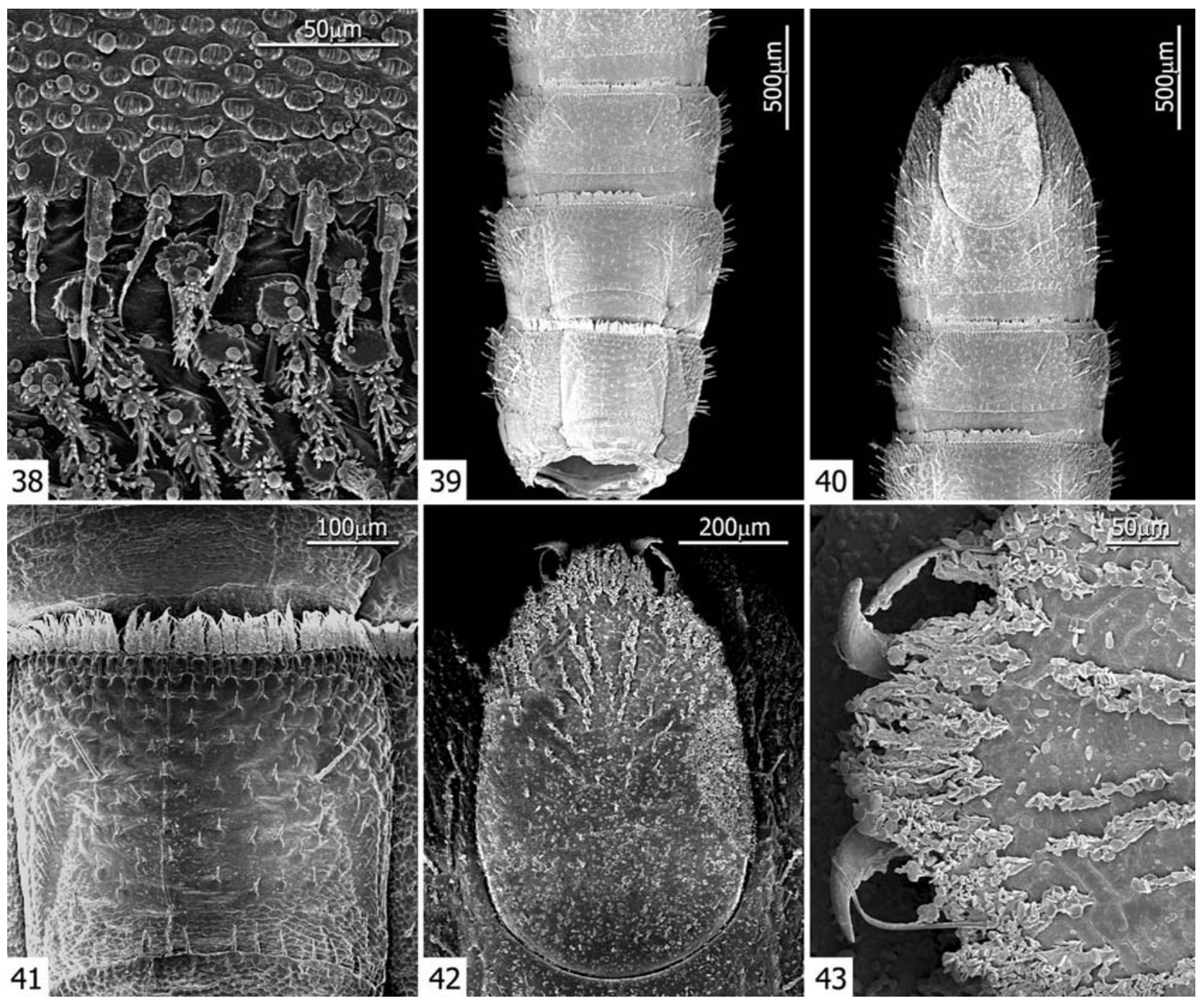

Figs 38-43. Hedyselmis opis larva: 38 - detail of abdominal dorsal surface; 39 - venter of abdominal segments 3-6; 40 - venter of abdominal segments 7-9; 41 - detail of abdominal sternum; 42 - abdominal operculum; 43 - apex of operculum with apical claws.

2 peg-like, with apical sensory field (Fig. 27); palpiger slightly wider than segment 2 . Postmentum undivided, elongate, widened apicad, with paired, distinctly long lateral setae; surface in apical fourth and along midline covered by long branched setae (Fig. 28). Hypopharynx simple.

Thorax. Protergum slightly longer than wide, widest in posterior half; anterior margin feebly arcuate; lateral sides slightly converging anteriad; disc without depressions or tubercles, with several bald microreticulate spots on posterior half (Fig. 1). Meso- and metatergum wider than long, about half as long as protergum, both with small admedian microreticulate spot on each side. Venter of prothorax (Fig. 29) with: (1) transverse basisternum (acuminately projected between coxae) fused with episterna; (2) paired epimera widened behind procoxae; (3) subpentagonal sternellum with short anterior acuminate projection between procoxae. Cervicosternum longer than wide, lightly sclerotized, folded between head capsule and probasisternum. Venter of mesothorax with small rudiments of episternum and epimeron separated by coxal cavities, basisternum large, transverse, fused with transversally triangular intersternite; portion behind coxae membranous; laterotergite bearing spiracle fused with tergum. Metathorax (Fig. 30) with episternum large; epimeron small, reduced; basisternum large, narrowed anteriad; portion behind coxae same as in mesothorax. Legs short (Figs 32-34), all subequal in length; each coxa subtriangular in ventral view, transverse in resting position, excavated ventrally; trochanter almost as long as femur, each ventrally with flattened spiky sensillum (Fig. 31); tibia slightly longer than femur, with few hair-like setae; claw (Fig. 35) slightly shorter than half length of tibia, moderately curved, grooved in distal half, with single stout seta on the middle of the ventral surface (Fig. 36).

Abdomen (Figs 37-43). Abdominal segments 1-8 simple, subequal in length, wider than long, distal margin of segments with row of spiky scales (Figs 37, 41); segments 1-7 with distinct tergum, paired elongate pleura and subquadrate sternum (Figs 39-41), segment 8 with all sclerites fused; segment 9 with apex rounded, posterior 


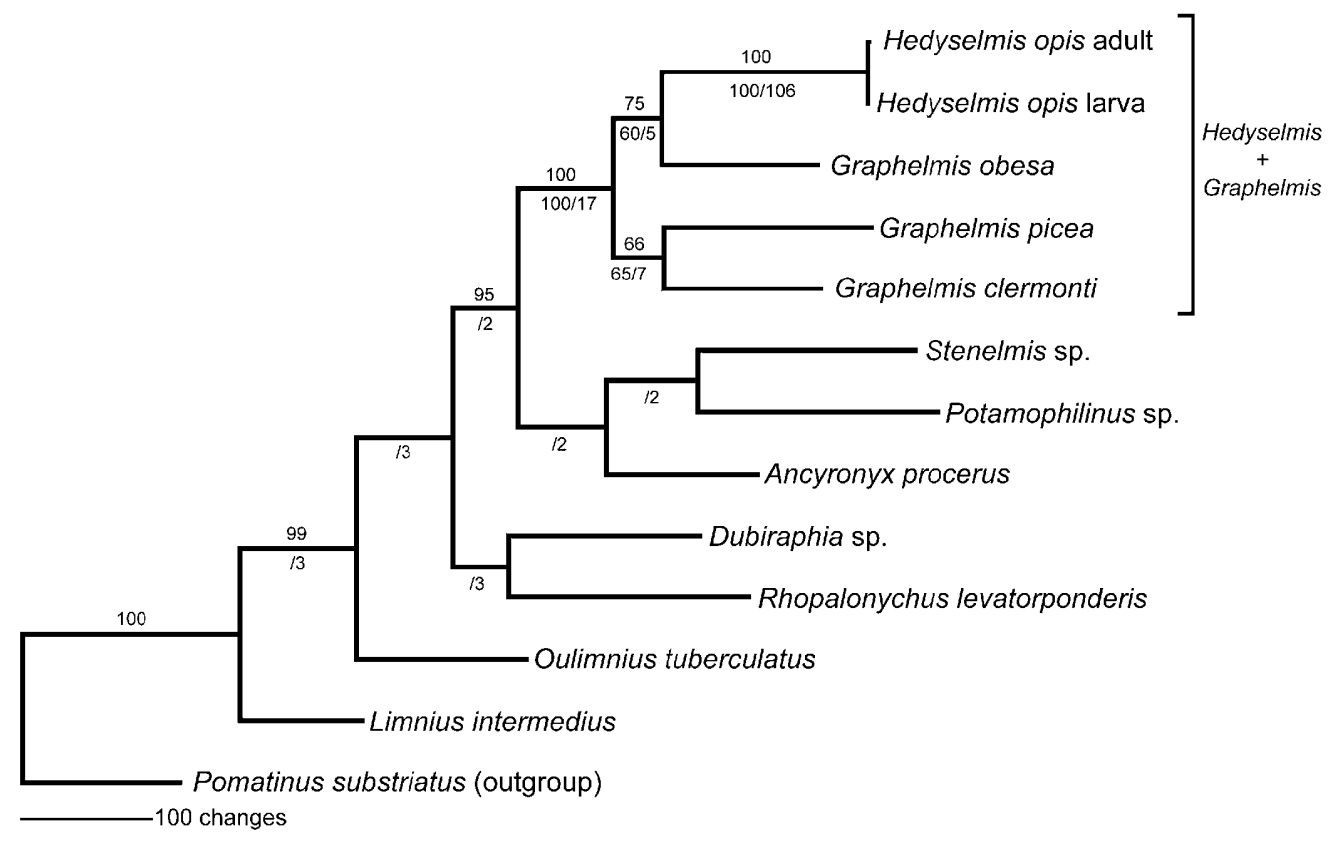

Fig. 44. Single most parsimonious tree obtained using the combined dataset. Above branches, posterior probability values $(\times 100)$ of the Bayesian analyses (only if $>0.5$ ); below branches, bootstrap (only if more than $50 \%$ ) / Bremer support values of the parsimony analyses.

0.6 flattened dorsally and strongly slanting posteriad; operculum (Fig. 42) oval, reaching apex of segment 9 with dense setae along distal margin; opercular claws well developed (Fig. 43). Anterior portion of segments (normally concealed by preceding segment) with grooved microgranules; exposed portion covered by dense, shortly branched setae inserted on small tubercles; line between these portions with hair-like setae (Fig. 38).

\section{DISCUSSION}

In Coleoptera almost identical sequences for the genes used in the present work are found only within the same species, usually from the same or closely linked populations (see e.g. Ribera et al., 2003). Although there are almost no available molecular data on species of Elmidae, it is very likely that the same is true for this family.

Some species in very closely related species complexes of recent origin may have nearly identical or identical mitochondrial haplotypes, even though they can be separated using morphological characters (e.g. Ribera \& Vogler, 2004). In our case, the genus has only two known, well-characterised species with presumably allopatric distributions (Jäch \& Boukal, 1997) and it is highly unlikely that there were larvae of a very closely related undescribed species of the same genus at the same locality (with no adults). Thus, it is highly likely the described larva belongs to Hedyselmis opis.

All our phylogenetic analyses support a close relationship between Hedyselmis and Graphelmis, as suggested by Jäch \& Boukal (1997). Hedyselmis and Graphelmis adults share several common characters (shape of prosternal process, fused third and fourth elytral stria, basal teeth on tarsal claws, shape of male pregenital segment), supporting this very close relationship (Jäch \& Boukal,
1997 and F. Čiampor Jr, unpubl. observ.). The larva of Graphelmis has not been formally described, but it is mentioned in Glaister (1999). Based on this work, as well as personal communication with the author, some larvae collected in Malaysia were preliminary assigned to the genus Graphelmis, although further study is needed to support this identification. These larvae are generally similar to those of Hedyselmis, differing only in having less flattened integument scales, paired spines on dorsal side of the abdominal segment 9, slightly longer legs and lighter colouration with a yellowish pattern.

Jäch \& Boukal (1997) suggest that Cephalolimnius Delève, 1973 is also a close relative of Hedyselmis. This assumption is supported by the wing venation and morphology of male unpaired sclerite of spiculum gastrale. Unfortunately specimens of this genus were not available for study, so the relationship Hedyselmis - Cephalolimnius could not be tested.

Although our study suggests that Graphelmis may be paraphyletic with respect to Hedyselmis, we refrain here from introducing any formal nomenclatorial change. Our sampling of Graphelmis, as well as the knowledge of their larval stages, is insufficient to allow a definitive inclusion of Hedyselmis within Graphelmis.

ACKNOWLEDGEMENTS. We wish to thank J. Kodada (Bratislava, Slovakia) and M.A. Jäch (Vienna, Austria) and three anonymous referees for their useful comments on the manuscript, and A. Glaister (Clayton, Australia) for her information on the Graphelmis larvae. M. Čiamporová (Bratislava, Slovakia) and A.F.G. Dixon (Norwich) are acknowledged for language review, and M. Balke (Munich, Germany) for his help with the molecular work. This study was partly supported by the Slovak Scientific Grant Agency, Projects No. 1/0114/03 and $1 / 3110 / 03$. Molecular analysis was sponsored by the European 
Union programme SYNTHESYS at the MNCN in Madrid, project ES-TAF 136.

\section{REFERENCES}

Balke M., Ribera I. \& Beutel R.G. 2005: The systematic position of Aspidytidae and the diversification of Dytiscoidea (Coleoptera, Adephaga). J. Zool. Syst. Evol. Res. 43: 223-242.

Barraclough T.G., Hogan J.E. \& Vogler A.P. 1999: Testing whether ecological factors promote cladogenesis in a group of tiger beetles (Coleoptera: Cicindelidae). Proc. R. Soc. Lond. (B) 266: 1061-1067.

BREMER K. 1994: Branch support and tree stability. Cladistics 10: $295-304$.

Brown H.P. 1987: Biology of riffle beetles. Annu. Rev. Entomol. 32: 253-273.

ČIAMPOR F. JR. 2005: Systematic revision of the genus Graphelmis (Coleoptera: Elmidae) VII. Graphelmis obesa species group. Entomol. Probl. 35: 117-122.

Felsenstein J. 1985: Confidence limits on phylogenies: an approach using the bootstrap. Evolution 39: 783-791.

Glaister A. 1999: Guide to the Identification of Australian Elmidae Larvae (Insecta: Coleoptera). Identification Guide No. 21. Cooperative Research Centre for Freshwater Ecology, Albury, $48 \mathrm{pp}$.

Hinton H.E. 1976: Hedyselmis, a new genus of Elmidae (Coleoptera) from Malaysia. Syst. Entomol. 1: 259-261.

Huelsenbeck J.P. \& RonQuist F. 2001: MrBAYES: Bayesian inference of phylogenetic trees. Bioinformatics 17: 754-755.

JÄсH M.A. \& BouKal D.S. 1997: The genus Hedyselmis Hinton (Coleoptera: Elmidae). Entomol. Probl. 28: 111-116.

JEON M.J. \& AHN K.J. 2005: First larval descriptions for Cafius Curtis (Coleoptera: Staphylinidae: Staphylininae) in Korea. J. Kans. Entomol. Soc. 78: 261-271.

LAWRENCE J.F. 1991: Order Coleoptera (larval morphology). In Stehr F.W. (ed.): Immature Insects, Vol. 2. Kendall/Hunt, Dubuque, Iowa, pp. 146-170.

Manzo V. \& Archangelsky M. 2001: Description of the larva of Macrelmis isis (Hinton, 1946), with distributional notes of the species (Coleoptera, Elmidae). Tijdschr. Entomol. 144: $45-54$.

Miller K.B., Alarie Y., Wolfe G.W. \& Whiting M.F. 2005: Association of insect life stages using DNA sequences: the larvae of Philodytes umbrinus (Motschulsky) (Coleoptera: Dytiscidae). Syst. Entomol. 30: 499-509.

Posada D. \& CRANDAll K.A. 1998: Modeltest: testing the model of DNA substitution. Bioinformatics 14: 817-818.

Ribera I. \& Vogler A.P. 2004: Speciation of Iberian diving beetles in Pleistocene refugia (Coleoptera, Dytiscidae). Mol. Ecol. 13: 179-193.

Ribera I., Bilton D.T. \& Vogler A.P. 2003: Mitochondrial DNA phylogeography and population history of Meladema diving beetles on the Atlantic Islands and in the Mediterranean basin (Coleoptera, Dytiscidae). Mol. Ecol. 12: 153-167.

Shull V.L., Vogler A.P., Baker M.D., Maddison D.R. \& HamMOND P.M. 2001: Sequence alignment of 18S ribosomal RNA and the basal relationships of Adephagan beetles: Evidence for monophyly of aquatic families and the placement of Trachypachidae. Syst. Biol. 50: 945-969.

Simon C., Frati F., Beckenbach A.T., Crespi B., Liu H. \& FLook P. 1994: Evolution, weighting, and phylogenetic utility of mitochondrial gene sequences and a compilation of conserved polymerase chain reaction primers. Ann. Entomol. Soc. Am. 87: 651-701.

SOREnSON M.D. 1996: TreeRot. University of Michigan, Ann Arbor, MI.

SPRINGER M. \& Acosta R. 2003: First description of the larva of Pharceonus Spangler et Santiago-Fragoso, 1992, and new records for the genus (Coleoptera: Elmidae: Larainae). Aquat. Insects 25: 219-223.

SwOFFord D.L. 2002: PAUP*. Phylogenetic analysis using parsimony (* and other methods), version 4.0b10. Sinauer, Sunderland, MA.

Wells J.D. \& SPerling F.A.H. 2001: DNA-based identification of forensically important Chrysomyinae (Diptera: Calliphoridae). Forensic Sci. Internat. 120: 110-115.

Received November 3, 2005; revised and accepted March 8, 2006 